\title{
Model Kepemimpinan Spiritual \\ Dalam Meningkatkan Kepuasan Kerja \\ Dan Kinerja Karyawan di BMT se-Kabupaten Pati
}

\author{
Anita Rahmawaty \\ Prodi Ekonomi Syari'ah, STAIN Kudus \\ itarahma1275@gmail.com
}

\begin{abstract}
Abstrak
Penelitian ini bertujuan untuk menganalisis model teoritis pengaruh kepemimpinan spiritual, budaya organisasi, komitmen organisasi terhadap kepuasan kerja dan kinerja karyawan. Data penelitian ini diperoleh dari 130 karyawan di BMT seKabupaten Pati. Teknik pengujian model penelitian ini menggunakan teknik analisis jalur (path analysis). Hasil penelitian ini menunjukkan bahwa kepemimpinan spiritual berpengaruh secara positif dan signifikan terhadap budaya organisasi, komitmen organisasi, kepuasan kerja dan kinerja karyawan. Namun demikian, dalam penelitian ini ditemukan pula bahwa budaya organisasi tidak berpengaruh secara signifikan terhadap kinerja karyawan. Dengan demikian, temuan penelitian menunjukkan bahwa kepemimpinan spiritual merupakan variabel penting yang mempengaruhi kepuasan kerja dan kinerja karyawan.
\end{abstract}

Kata Kunci: Kepemimpinan spiritual, budaya organisasi, komitmen organisasi, kepuasan kerja, kinerja karyawan.

\section{Abstract}

This research aims to analyze the theoretical model of the effect of spiritual leadership, organizational culture, organizational commitment on job satisfaction and employee performance. The research data are obtained from 130 employees of BMT in Pati. The research model testing technique uses the path analysis 
approach. The results showed that spiritual leadership positively and significantly effects on organizational culture, organizational commitment, job satisfaction and employee performance. Nevertheless, in this research, it is found also that organizational culture is not related to employee performance. Thus, the research findings suggest that spiritual leadership is the important variable that affect on job satisfaction and employee performance.

Keywords: Spiritual leadership, organizational culture, organizational commitment, job satisfaction, employee performance.

\section{PENDAHULUAN}

Beberapa dekade terakhir ini, penguatan nilai-nilai spiritual dalam manajemen sumber daya manusia (SDM) telah menjadi trend perbincangan dalam kajian bisnis. Hal ini disebabkan karena berbagai praktek perusahaan atau lembaga keuangan yang tidak terpuji dan menimbulkan dampak negatif, tidak terlepas dari manajemen SDM yang jauh dari nilai-nilai spiritual. Bahkan kinerja karyawan hanya dipacu dengan pencapaian indikator ekonomi tanpa dilandasi dengan nilai-nilai spiritual (Sulistyo, 2009).

Kepemimpinan dianggap sebagai faktor penting yang sangat menentukan keberhasilan suatu organisasi. Kepemimpinan yang baik dalam suatu organisasi dapat meningkatkan kinerja karyawannya, dan demikian pula sebaliknya. Selama ini, mainstream kepemimpinan transaksional maupun transformasional lebih menekankan pada aspek karakter maupun perilaku. Hasil riset tentang teori perilaku kepemimpinan dapat disimpulkan bahwa tidak satupun teori kepemimpinan yang menjamin kemungkinan sukses sebagai pemimpin. Hal ini disebabkan karena selama ini model-model kepemimpinan yang ada masih memandang bahwa hakekat kepemimpinan merupakan amanat dari manusia dan bukan suatu amanat dari Tuhan dan juga manusia. Anggota dalam suatu organisasi didorong dengan materi dan daya tarik altruistik dengan mengabaikan nilai-nilai keteladanan. Konsekuensinya, 
kinerja yang dicapai semata-mata bertujuan untuk tercapainya tujuan organisasi dan bukan tanggung jawab manusia kepada Tuhan (Sulistyo, 2009).

Saat ini, telah berkembang konsep kepemimpinan spiritual yang merupakan konsep kepemimpinan universal yang adaptif untuk menjawab tantangan zaman pada era abad ke-21 yang syarat dengan perubahan, yang tidak terjawab oleh kepemimpinan organisasi saat ini (Sureskiarti, 2015). Menurut Tobroni (2005), konsep kepemimpinan spiritual ini diyakini sebagai solusi terhadap krisis kepemimpinan saat ini, akibat semakin merosotnya nilai-nilai kemanusiaan sebagai dampak dari adanya ethical malaise dan ethical crisis.

Uraian di atas menggambarkan bahwa persoalan spiritualitas semakin diterima dalam abad ke-21, sebagaimana dikemukakan oleh para futurolog, seperti Aburdene dan Fukuyama sebagai abad nilai (the value age). Spiritualitas telah terbukti menjadi kekuatan yang luar biasa untuk menciptakan individu-individu yang memiliki integritas dan akhlaqul karimah yang mampu membangun masyarakat Islam mencapai puncak peradaban dan mencapai predikat khaira ummat (Tobroni, 2005). Oleh karena itu, penerapan kepemimpinan spiritual dalam suatu organisasi/perusahaan akan dapat menginspirasi dan memotivasi sumber daya manusia dalam mencapai visi dan budaya organisasi yang didasarkan pada nilai-nilai spiritual, yang pada akhirnya dapat meningkatkan komitmen organisasi dan kinerja karyawan secara produktif.

Beberapa riset terdahulu mengenai kepemimpinan spiritual telah dikembangkan dengan berbagai variasi peristilahan yang semakin menarik dan diaplikasikan dalam konteks yang berbeda, baik di lembaga keuangan dan perbankan, lembaga pendidikan maupun rumah sakit. Studi Hakim (2012) menunjukkan bahwa Islamic leadership memiliki peranan penting dalam meningkatkan Islamic work motivation dan Islamic performance di PT Bank Muamalat Indonesia Tbk di Jawa Tengah. Studi Rahim (2014) menguji Islamic leadership dan pengaruhnya employee welfare di beberapa Universitas Islam Sulawesi Utara. Sedangkan studi Sureskiarti (2015) menguji pengaruh spiritual leadership terhadap kinerja perawat di RSUD Dr. H. Soewondo Kendal. 
Di samping itu, beberapa riset terdahulu juga menunjukkan bahwa riset tentang model kepemimpinan spiritual dalam meningkatkan kinerja, ternyata masih memiliki perbedaan atau kesenjangan hasil penelitian. Studi Musta'in dan Manan (2014) menunjukkan bahwa kepemimpinan spiritual berpengaruh secara signifikan terhadap kepuasan kerja dan meningkatkan kinerja karyawan di Universitas Darul Ulum, Jombang. Studi Shofwa (2013) juga membuktikan bahwa kepemimpinan spiritual berpengaruh secara signifikan terhadap kinerja karyawan STAIN Purwokerto. Namun berbeda dengan hasil riset di atas, studi Sulistyo (2009) menunjukkan bahwa kepemimpinan spiritual tidak berpengaruh secara signifikan terhadap kepuasan kerja dan kinerja karyawan. Dengan demikian, beberapa riset empiris di atas menunjukkan masih terdapat inkonsistensi hubungan secara teoritis antara kepemimpinan spiritual terhadap kepuasan kerja dan kinerja karyawan.

Selain kepemimpinan spiritual, terdapat beberapa faktor penting yang memiliki peran dalam meningkatkan kinerja karyawan. Kinerja karyawan yang produktif dan optimal merupakan salah satu sasaran organisasi untuk mencapai produktivitas kerja yang tinggi. Kinerja karyawan dapat dinilai melalui tingkat keberhasilannya dalam melaksanakan tugas dan tanggung jawabnya. Secara umum, kinerja karyawan secara umum dipengaruhi oleh dua faktor, yaitu faktor internal, seperti komitmen organisasi dan kepuasan kerja dan faktor eksternal, seperti kepemimpinan, budaya organisasi, keselamatan kerja, dan lain-lain (Taurisa dan Ratnawati, 2012).

Salah satu faktor eksternal yang mempengaruhi kinerja karyawan adalah budaya organisasi. Budaya organisasi menjadi pembeda suatu organisasi dengan organisasi lainnya. Beberapa organisasi mampu bertahan terhadap berbagai perubahan serta tantangan eksternal karena memiliki kekuatan budaya organisasi, dan sebaliknya tidak sedikit organisasi yang roboh karena tidak memiliki kekuatan budaya organisasi (Hatta dan Rachbini, 2015). Nilai-nilai dalam budaya organisasi akan membentuk sikap kerja dan perilaku yang produktif dan pada akhirnya dapat mendorong peningkatan kinerja karyawan. 
Faktor penting yang perlu dipertimbangkan juga dalam meningkatkan kinerja karyawan adalah komitmen organisasi. Komitmen organisasi merupakan sikap yang merefleksikan loyalitas karyawan pada organisasi dan proses berkelanjutan, di mana anggota organisasi mengekspresikan perhatiannya terhadap keberhasilan organisasi dan kemajuan yang berkelanjutan (Noor, 2012). Komitmen seorang karyawan terhadap organisasinya dapat menjadi instrumen penting untuk meningkatkan kinerjanya. Selain itu, komitmen organisasi juga memiliki keterkaitan dengan budaya organisasi. Keharmonisan tujuan yang dicapai antara karyawan dan organisasi melalui budaya organisasi akan membangun suatu komitmen organisasi dalam diri karyawan (Taurisa dan Ratnawati, 2012).

Kepuasan kerja merupakan faktor internal lain yang mempengaruhi kinerja karyawan. Kepuasan kerja dapat didefinisikan sebagai suatu keadaan emosional yang menyenangkan atau tidak menyenangkan, yang ditunjukkan oleh karyawan dalam bekerja (Hatta dan Rachbini, 2015). Tingkat kepuasan kerja karyawan dipengaruhi oleh beberapa aspek, baik aspek yang berasal dari perusahaan maupun berasal dari diri karyawan tersebut. Aspek yang berasal dari organisasi/perusahaan, di antaranya adalah budaya organisasi yang selalu melekat pada setiap perusahaan, sedangkan aspek yang berasal dari diri karyawan, di antaranya adalah komitmen yang diberikan karyawan terhadap perusahaan (Noor, 2012). Dengan demikian, secara teoritis, budaya organisasi, komitmen organisasi dan kepuasan kerja memiliki hubungan yang erat dalam mempengaruhi kinerja karyawan.

Hubungan secara teoritis tersebut didukung oleh beberapa penelitian terdahulu, namun beberapa penelitian empiris tersebut menunjukkan belum ada konsistensi pengaruh antar variabel. Studi Taurisa dan Ratnawati (2012) menunjukkan bahwa budaya organisasi berpengaruh positif dan signifikan terhadap komitmen organisasi. Studi Nurjanah (2008) juga mendukung hasil riset di atas bahwa budaya organisasi berpengaruh secara signifikan terhadap komitmen organisasi. Namun, berbeda dengan hasil riset di atas, studi Logahan dan Aesaria (2014) mengemukakan bahwa budaya organisasi tidak memiliki pengaruh terhadap komitmen organisasi. 
Studi yang dilakukan oleh Ghozali (2002) dengan menggunakan teknik analisis Structural Equation Model (SEM) menunjukkan bahwa komitmen organisasi berpengaruh secara signifikan terhadap kepuasan kerja. Hasil riset ini juga didukung oleh studi Widagdo et al. (2013) bahwa komitmen organisasi memiliki pengaruh positif dan signifikan terhadap kepuasan kerja. Namun demikian, studi Sunarno dan Liana (2015) menunjukkan hasil yang berbeda bahwa komitmen organisasi tidak berpengaruh secara signifikan terhadap kepuasan kerja.

Pengaruh positif dan signifikan antara komitmen organisasi dan kinerja karyawan telah ditunjukkan oleh studi Taurisa dan Ratnawati (2012). Namun demikian, studi Logahan dan Aesaria (2014) mengungkapkan hasil yang berbeda bahwa komitmen organisasi tidak memiliki pengaruh terhadap kinerja karyawan. Studi ini juga didukung oleh hasil riset Noor (2012) bahwa komitmen organisasi tidak berpengaruh terhadap kinerja karyawan.

Studi Sunarno dan Liana (2015) mengungkapkan pula bahwa kepuasan kerja berpengaruh secara signifikan terhadap kinerja karyawan. Namun, berbeda dengan hasil riset di atas, ternyata studi Sulistyo (2009) menunjukkan bahwa kepuasan kerja tidak berpengaruh secara signifikan terhadap kinerja karyawan Telkom Divre IV Jawa Tengah.

Atas dasar review riset terdahulu di atas, masih terdapat kesenjangan hasil penelitian (gap research) yang berbeda mengenai model kepemimpinan spiritual dan faktor-faktor yang dapat meningkatkan kinerja karyawan. Oleh karena itu, penelitian ini difokuskan untuk menguji pengaruh kepemimpinan spiritual, budaya organisasi dan komitmen organisasi terhadap kepuasan kerja dan kinerja karyawan.

Penelitian ini diharapkan dapat memberikan kontribusi dalam penguatan dan pengembangan BMT dan Lembaga Keuangan Mikro Syariah (LKMS) melalui pengembangan model kepemimpinan spiritual, budaya organisasi dan komitmen organisasi. Harapannya, penelitian ini dapat dijadikan rujukan sebagai model kepemimpinan spiritual pada BMT dan LKMS serta memberikan kontribusi kepada para praktisi, baik praktisi BMT maupun LKMS dalam menentukan kebijakan usaha dalam rangka pengembangan bisnis syari'ah. 


\section{KAJIAN LITERATUR}

\section{Kepemimpinan Spiritual (Spiritual Leadership)}

Konsep kepemimpinan spiritual muncul sebagai sebuah paradigma baru dalam transformasi dan perkembangan organisasi yang adaptif untuk menjawab tantangan zaman pada era abad ke-21. Kepemimpinan spiritual ini dipandang mampu menyempurnakan model-model kepemimpinan sebelumnya dengan cara mendasarkan visi, misi dan perilaku kepemimpinannya pada nilai-nilai ketuhanan (Tobroni, 2005).

Kepemimpinan spiritual adalah kepemimpinan yang membawa dimensi keduniaan kepada dimensi spiritual (keilahian). Karena itu, kepemimpinan spiritual sering disebut juga kepemimpinan yang berdasarkan pada etika relijius. Tobroni (2015) mengemukakan bahwa kepemimpinan spiritual adalah kepemimpinan yang mampu mengilhami, membangkitkan, mempengaruhi dan menggerakkan melalui keteladanan, pelayanan, kasih sayang dan implementasi nilainilai dan sifat-sifat ketuhanan lainnya dalam tujuan, proses budaya dan perilaku kepemimpinan. Dengan kata lain, kepemimpinan spiritual merupakan kepemimpinan yang menjadikan nilai-nilai spiritual sebagai core belief, core values dan filosofi dalam perilaku kepemimpinannya.

Secara historisitas Islam, model kepemimpinan spiritual ini dapat merujuk kepada pola kepemimpinan yang diterapkan oleh Nabi Muhammad SAW yang mampu mengembangkan kepemimpinan yang paling ideal dan sukses dengan sifatsifatnya yang utama, yaitu siddiq (integrity), amanah (trust), dan tabligh (openly, human relation) dan fathanah (working smart). Dengan kata lain, kepemimpinan spiritual adalah kepemimpinan yang memimpin dengan hati berdasarkan pada etika religius, mampu membentuk karakter, integritas dan keteladanan. Model kepemimpinannya tidak dipengaruhi oleh faktor-faktor eksternal semata, melainkan lebih banyak dibimbing oleh faktor internal hati nuraninya. Namun demikian, kepemimpinan spiritual bukan berarti kepemimpinan yang anti intelektual. Kepemimpinan spiritual bukan hanya sangat rasional, melainkan justru menjemihkan rasionalitas dengan bimbingan hati nurani dan kecerdasan spiritual (Tobroni, 2015). 
Salah satu teori kepemimpinan spiritual yang telah berkembang saat ini adalah Spiritual Leadership Theory (SLT) yang diperkenalkan oleh Louis W. Fry pada tahun 2003 dan dikembangkan lagi pada tahun 2005. Spiritual Leadership Theory adalah suatu model kepemimpinan yang menggunakan model motivasi intrinsik dengan menggabungkan adanya visi (vision), harapan/keyakinan (hope/faith), dan nilai altruism (altruistic love) serta spiritualitas di tempat kerja (workplace spirituality), dan kesejahteraan spiritual/ spiritual survival (Fry et al., 2005). Spiritual Leadership Theory ini telah banyak diterapkan secara universal di berbagai setting tempat kerja. Louis W. Fry (2005) mendefinisikan spiritual leadership sebagai berikut:

"The values, attitudes, and behaviors required to intrinsically motivate one's self and others in order to have a sense of spiritual survival through calling and membershipi.e., they experience meaning in their lives, have a sense of making a difference, and feel understood and appreciated".

Pernyataan di atas mengandung makna bahwa kepemimpinan spiritual merupakan sebuah nilai, sikap dan perilaku pemimpin yang diperlukan dalam upaya memotivasi diri sendiri maupun orang lain melalui calling (perasaan memiliki makna) dan membership (perasaan dihargai dan dimengerti) sehingga terbentuk perasaan sejahtera secara spiritual.

Oleh karena itu, kepemimpinan spiritual ini bertujuan untuk memotivasi dan menginspirasi para karyawan melalui penciptaan visi dan budaya yang didasarkan pada nilai-nilai altruistik untuk menghasilkan para tenaga kerja yang memiliki komitmen organisasi dan produktivitas (Fry et al., 2005).

Model Spiritual Leadership Theory ini dapat digambarkan sebagai berikut: 


\section{Gambar 1 \\ Model of Spiritual Leadership Theory}

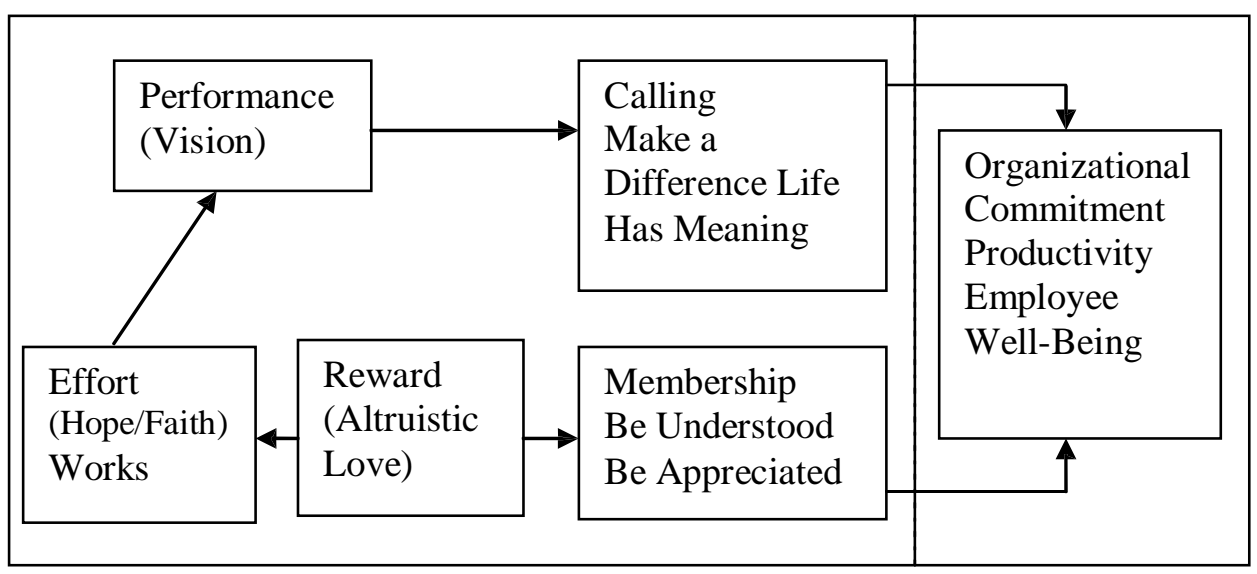

Leader Values, Attitude \&

Behaviors

Follower Needs for
Spiritual Survival

Organizational

Outcomes

Sumber: Fry (2005)

Gambar di atas mendeskripsikan bahwa dalam model Spiritual Leadership Theory terdapat 3 (tiga) dimensi utama dan 6 (enam) variabel yang membentuk kerangka dasar teori ini, yaitu: (1) dimensi leader values, attitude and behaviors (nilai, sikap dan perilaku pemimpin), yang meliputi: vision (visi), hope/faith (keyakinan) dan altruistic love; (2) dimensi spiritual survival, yang meliputi: calling dan membership; dan (3) dimensi organizational outcomes, yaitu komitmen organisasi (Fry et al., 2005). Hal inilah yang dipandang dapat membantu terciptanya kepuasan dari para sumber daya manusia akan kebutuhanya terhadap spiritualitas melalui calling (perasaan memiliki makna) dan membership (perasaan dihargai dan dimengerti), yang pada akhirnya dapat meningkatkan kinerja karyawan dan kinerja organisasi.

Studi Fry et al. (2005) mengenai model kausal spiritual leadership theory menunjukkan bahwa terdapat hubungan positif antara kualitas spiritual leadership, spiritual survival 
dengan organizational outcomes, yang terdiri dari komitmen dan produktivitas. Nilai-nilai kepemimpinan spiritual yang dikembangkan oleh Fry et al. (2005) adalah: vision, hopelfaith, altruistic love (trust, forgiveness, integrity, honesty, courage, humility, kindness, empathy, patience). Nilai-nilai spiritualitas dalam bekerja juga dikembangkan oleh Giacalone \& Jurkiewicz (dalam Sulistyo, 2009) antara lain: honesty, forgiveness, hope, gratitude, humility, compassion dan integrity.

Sementara itu, Tobroni (2015) mengemukakan beberapa karakteristik kepemimpinan spiritual adalah sebagai berikut: true honesty, fairness, the spirit of pious deed, the hatred of formality and organized religion, little talk, hard work and relax, arousing the best for our self and others, openess to the change, beloved leaders, think globally and act locally, discipline, smart and enthusiastic dan modesty.

Beberapa studi telah menyatakan pentingnya nilai-nilai spiritualitas dalam organisasi. Nilai-nilai spiritual dalam kepemimpinan mampu memotivasi dan menginspirasi para karyawan dalam membangun visi dan budaya organisasi serta menciptakan komitmen karyawan terhadap organisasi, yang pada akhirnya juga berdampak pada peningkatan kepuasan kerja dan kinerja karyawan.

\section{Budaya Organisasi (Organizational Culture)}

Definisi budaya organisasi banyak dikemukakan oleh para pakar. Mowat (dalam Widagdo et al., 2013) mendefinisikan budaya organisasi adalah: "the personality of the organization the shared beliefs, values and behaviors of the group. It is simbolic, holistic and unifying, stable, and difficult to change". Kreitner dan Angelo (dalam Noor, 2012) mengemukakan bahwa budaya organisasi merupakan bagian nilai-nilai dan kepercayaan yang mendasari identitas organisasi/perusahaan. Hofstede (dalam Taurisa dan Ratnawati, 2012) menjelaskan budaya organisasi sebagai interaksi dari ciri-ciri kebiasaan yang mempengaruhi kelompok-kelompok orang dalam lingkungannya. Robbins dan Judge (dalam Logahan dan Aesaria, 2014) mengungkapkan budaya organisasi sebagai sistem makna bersama terhadap nilai-nilai primer yang dianut bersama dan dihargai organisasi, yang berfungsi menciptakan 
pembedaan yang jelas antara satu organisasi dengan organisasi lainnya. Berdasarkan beberapa definisi di atas, dapat disimpulkan bahwa budaya organisasi merupakan suatu sistem makna bersama yang dianut oleh para anggota organisasi yang membedakan organisasi itu dari organisasi-organisasi lainnya.

Hatta dan Rachbini (2015) mengemukakan bahwa budaya organisasi ini memiliki peran untuk menciptakan perbedaan yang jelas antara satu organisasi dengan organisasi lainnya, menciptakan rasa identitas bagi para anggota organisasi, mempermudah timbulnya komitmen kolektif terhadap organisasi, meningkatkan kemantapan sistem sosial, serta menciptakan mekanisme pembuat makna dan kendali yang memandu dan membentuk sikap dan perilaku para anggota organisasi. Oleh karena itu, budaya organisasi harus diciptakan, dipertahankan, diperkuat dan diperkenalkan kepada karyawan melalui proses sosialisasi berupa tujuan, strategi, nilai-nilai dan standar perilaku organisasi serta informasi yang berhubungan dengan pekerjaan.

Budaya organisasi memiliki banyak dimensi-dimensi yang mempengaruhi perilaku. Morrey dan Luthans (dalam Sopiah, 2008) menyebutkan 7 (tujuh) dimensi budaya organisasi, yaitu: (1) hubungan manusia dengan alam; (2) individualisme versus kolektivisme; (3) orientasi waktu; (4) orientasi aktivitas; (5) informalitas; (6) bahasa; dan (7) kepercayaan. Sedangkan Robbins dan Judge (dalam Logahan dan Aesaria, 2014) mengemukakan 7 (tujuh) ciri-ciri budaya organisasi, adalah: (1) inovasi dan keberanian pengambilan risiko; (2) perhatian pada hal-hal yang detail; (3) orientasi pada manfaat/hasil; (4) orientasi pada manusia; (5) orientasi pada tim; (6) agresivitas; dan (7) stabilitas. Sedangkan Hofstede, et.al, (1993) mengemukakan dimensi-dimesi budaya organisasi sebagai berikut: (1) professionalism; (2) distance from management; (3) trust in colleagues; (4) orderliness; dan (5) integration.

Keberhasilan suatu organisasi/perusahaan sangat tergantung kepada keberhasilannya dalam menciptakan budaya organisasi yang khas sebagai bagian dari rencana strategik. Oleh karena itu, pengelolaan budaya organisasi diarahkan pada kemampuan budaya dalam mendorong meningkatnya kinerja organisasi/perusahaan melalui kinerja karyawan. 


\section{Komitmen Organisasi (Organizational Commitment)}

Komitmen organisasi merupakan dimensi perilaku penting yang dapat digunakan untuk menilai kecenderungan karyawan untuk bertahan sebagai anggota organisasi. Definisi komitmen organisasi banyak dikemukakan oleh para pakar. Mathins dan Jackson (dalam Sopiah, 2008) mendefinisikan "organizational commitment to the degree to which employees believe in and accept organizational goals and desire to remain with the organization". Durkin dan Bennet (dalam Sunarno dan Liana, 2015) mengemukakan komitmen organisasi sebagai perasaan yang kuat dan erat terhadap tujuan dan nilai suatu organisasi dalam hubungannya dengan peran mereka terhadap upaya pencapaian tujuan dan nilai-nilai tersebut. Luthans (dalam Noor, 2012) menjelaskan komitmen organisasi sebagai keinginan kuat untuk tetap menjadi anggota organisasi tertentu, berusaha keras sesuai keinginan organisasi dan menerima nilai dan tujuan organisasi. Dengan demikian, seseorang yang memiliki komitmen terhadap organisasinya akan lebih dapat bertahan sebagai bagian dari organisasi tersebut dibandingkan dengan anggota yang tidak memiliki komitmen organisasi.

Sementara itu, Ganesan dan Weitz (1996) mengemukakan bahwa komitmen organisasi adalah "the relative strength of an individual's identification and involvement in a particular organization". Senada dengan pendapat di atas, Greenberg dan Baron (dalam Wibowo, 2015) mengartikan komitmen organisasi sebagai suatu tingkatan di mana individu mengidentifikasi dan terlibat dengan organisasinya dan/ atau tidak ingin meninggalkannya.

Komitmen organisasi itu bersifat multidimensi. Luthans, et.al, (dalam Wibowo, 2015) mengajukan 3 (tiga) komponen komitmen organisasi, sebagai berikut: (1) affective commitment, menyangkut keterkaitan emosional karyawan, identifikasi dan keterlibatan dalam organisasi. Hal ini merupakan alasan emosional (emotion-based), dapat berupa perasaan persahabatan, iklim atau budaya perusahaan dam perasaan senang ketika menyelesaikan pekerjaan; (2) continuance commitment, menyangkut keterkaitan dengan kesadaran anggota organisasi sehingga anggota organisasi merasa akan mengalami kerugian jika meninggalkan organisasi. Ini merupakan cost- 
besed reason, termasuk masalah gaji, tunjangan dan promosi; (3) normative commitment, menyangkut perasaan karyawan atas kewajiban untuk tetap tinggal dengan organisasi karena hal itu merupakan yang terbaik untuk dilakukan. Ini adalah alasan obligation-based untuk tetap berada dalam organisasi, termasuk perasaan hutang budi pada atasan, kolega atau perusahaan.

Sementara itu, Ganesan dan Weitz mengidentifikasi komitmen organisasi sebagai berikut: (1) perasaan menjadi bagian dari organisasi; (2) kebanggaan terhadap organisasi; (3) kepedulian terhadap organisasi; (4) hasrat yang kuat untuk berkerja pada organisasi; kepercayaan yang kuat terhadap nilai-nilai organisasi; dan (6) kemauan yang besar untuk berusaha bagi organisasi.

Dengan demikian, karyawan yang memiliki komitmen organisasi yang tinggi, maka akan mengembangkan pola pandang yang lebih positif terhadap organisasi, memberikan yang terbaik kepada organisasi dan merasa senang hati tanpa paksaan mengeluarkan energi ekstra untuk kepentingan organisasi.

\section{Kepuasan Kerja (Job Satisfaction)}

Kepuasan kerja merupakan sikap umum seorang karyawan terhadap pekerjaannya. Definisi kepuasan kerja banyak dikemukakan oleh para pakar. Lock (dalam Sopiah, 2008) mendefinisikan "Job satisfaction is a pleasureable or positive emotional state resulting from the appraisal of one's job or job experience". Mathins and Jackson (dalam Sopiah, 2008) menjelaskan bahwa "Job satisfaction is a positive resulting one's job experience". Kreitner dan Kinicki (dalam Wibowo, 2015) mengungkapkan bahwa kepuasan kerja adalah respon afektif atau emosional terhadap berbagai aspek dari pekerjaan seseorang. Handoko (dalam Widagdo et al., 2013) mengemukakan bahwa kepuasan kerja merupakan keadaan emosional yang menyenangkan atau tidak menyenangkan di mana karyawan memandang pekerjaan mereka. Senada dengan definisi di atas, Robbins dan Judge (dalam Taurisa dan Ratnawati, 2012) mengartikan kepuasan kerja sebagai sikap positif karyawan terhadap pekerjaannya, yang timbul berdasarkan penilaian terhadap situasi kerja. 
Kepuasan kerja berhubungan erat dengan sikap karyawan terhadap pekerjaannya sendiri. Tingkat kepuasan kerja seseorang akan tercermin dalam sikap kerja ke arah positif. Oleh karena itu, kepuasan kerja harus diciptakan sebaik-baiknya supaya moral kerja, dedikasi, kecintaan, kedisiplinan dan kinerja karyawan akan meningkat (Sunarno dan Liana, 2015).

Menurut Taurisa dan Ratnawati, (2012), kepuasan kerja yang dirasakan karyawan tersebut dipengaruhi oleh 2 (dua) faktor, yaitu faktor intrinsik dan ekstrinsik. Faktor intrinsik adalah faktor yang berasal dari dalam diri individu yang dibawa setiap karyawan sejak mulai bekerja di tempat kerjanya, sedangkan faktor ekstrinsik merupakan faktor yang menuangkut hal-hal yang berasal dari luar diri karyawan, seperti kondisi fisik lingkungan kerja, interkasi dengan karyawan lain, sistem penggajian, dan lain-lain.

Schermerhorn, Jr., John R., James G. Hunt., Richard N. Osborn dan Mary Uhl-Bien (dalam Wibowo, 2015) mengemukakan bahwa terdapat 2 (dua) model yang dapat dipergunakan untuk mengukur kepuasan kerja, yaitu: The Minnesota Satisfaction Questionnaire (MSQ) dan Job Discriptive Index. The Minnesota Satisfaction Questionnaire (MSQ) mengukur kepuasan kerja meliputi: (1) working conditions; (2) chances for advancement; (3) freedom to use one's judgment; (4) praise for doing a good job; dan (5) feelings of accomplishment. Sedangkan Job Satisfaction Index mengukur kepuasan kerja dengan menggunakan 5 (lima) indikator, yaitu: (1) the work it self; (2) quality of supervision; (3) relationship with co-workers; (4) promotion opportunities; dan (5) pay.

Sementara itu, Scott J. Vitell \& D.L. Davis (1990) mengukur kepuasan kerja dengan indikator-indikator dari Job Satisfaction Index sebagai berikut: satisfaction with pay, satisfaction with promotions, satisfaction with co-workers, satisfaction with supervisors, dan satisfaction with the work it self.

Pekerjaan menuntut interaksi dengan rekan kerja dan atasan, mengikuti aturan dan kebijakan organisasi, memenuhi standar kinerja, hidup pada kondisi kerja yang sering kurang ideal dan hal serupa lainnya. Oleh karena itu, setiap individu akan memiliki tingkat kepuasan yang berbeda-beda sesuai dengan sistem nilai yang berlaku pada dirinya. Semakin banyak 
aspek-aspek dalam pekerjaan yang sesuai dengan keinginan individu tersebut, maka semakin tinggi tingkat kepuasan kerja yang dirasakannya dan sebaliknya.

\section{Kinerja Karyawan (Employee Performance)}

Kinerja atau performance mengacu pada sesuatu yang berhubungan dengan kegiatan dalam suatu pekerjaan, meliputi hasil yang dicapai kerja tersebut (Mahmudi, 2005). Definisi kinerja telah banyak dikemukakan oleh para ahli. Cherington (dalam Umam, 2012) mendefinisikan kinerja sebagai pencapaian target kerja yang berkaitan dengan kualitas, kuantitas dan waktu. Rogers (dalam Mahmudi, 2005) menjelaskan kinerja sebagai hasil kerja itu sendiri (outcomes of work) karena hasil kerja memberikan keterkaitan terhadap tujuan strategik organisasi, kepuasan pelanggan dan kontribusi ekonomi. Senada dengan pendapat di atas, Taurisa dan Ratnawati (2012) mengemukakan kinerja merupakan hasil kerja secara kualitas maupun kuantitas yang dicapai oleh seseorang dalam melaksanakan tugas yang diberikan kepadanya sesuai dengan standar atau kriteria yang telah ditetapkan.

Dengan demikian, seorang karyawan akan memiliki tingkat kinerja yang tinggi jika terdapat kesesuaian antara pekerjaan dan kemampuannya. Jika hal-hal tersebut terpenuhi, maka akan timbul perasaan tanggung jawab terhadap pekerjaannya dan kesediaan untuk ikut berpartisipasi dalam mencapai tujuan organisasi melalui pelaksanaan tugas-tugas secara maksimal. Oleh karena itu, organisasi perlu memperhatikan pengelolaan sumber daya manusia untuk menghasilkan kinerja yang tinggi agar dapat meningkatkan kinerja organisasi secara keseluruhan (Taurisa dan Ratnawati, 2012).

Berkaitan dengan standar kinerja, Mangkunegara (dalam Logahan dan Aesaria (2014) mengemukakan bahwa standar pekerjaan terdiri dari aspek kuantitatif dan kualitatif, yaitu: (1) aspek kuantitatif, yaitu: proses kerja dan kondisi pekerjaan, waktu yang dipergunakan melaksanakan pekerjaan, jumlah kesalahan dalam melaksanakan pekerjaan serta jumlah dan jenis pemberian pelayanan dalam bekerja; dan (2) aspek kualitatif, yaitu: ketepatan kerja dan kualitas pekerjaan, tingkat kemampuan dalam bekerja, kemampuan menganalisis 
data/informasi, kemampuan menggunakan mesin/peralatan, dan kemampuan mengevaluasi (keluhan konsumen/masyarakat).

Sementara itu, Tsui et al. (1997) mengukur standar kinerja keryawan dengan indikator-indikator sebagai berikut: quantity of work, quality of work, efficiency, standars of work quality, strives for higher work, professional standars, ability, judgment, accuracy, job knowledge, dan creativity.

Bertitik tolak dari pembahasan terdahulu, maka dapat diungkap bahwa terdapat keterkaitan antara kepemimpinan spiritual, budaya organisasi, komitmen organisasi dan kepuasan kerja dengan kinerja karyawan. Atas dasar kerangka pemikiran teoritis tersebut, maka hipotesis yang diuji dalam penelitian ini adalah:

$\mathrm{H}_{1}$ : Kepemimpinan spiritual berpengaruh secara positif dan signifikan terhadap budaya organisasi.

$\mathrm{H}_{2}$ : Kepemimpinan spiritual berpengaruh secara positif dan signifikan terhadap komitmen organisasi.

$\mathrm{H}_{3}$ : Budaya organisasi berpengaruh secara positif dan signifikan terhadap komitmen organisasi.

$\mathrm{H}_{4}$ : Budaya organisasi berpengaruh secara positif signifikan terhadap kepuasan kerja.

$\mathrm{H}_{5}$ : Komitmen organisasi berpengaruh secara positif signifikan terhadap kepuasan kerja.

$\mathrm{H}_{6}$ : Kepemimpinan spiritual berpengaruh secara positif dan signifikan terhadap kepuasan kerja.

$\mathrm{H}_{7}$ : Kepuasan kerja berpengaruh secara positif dan signifikan terhadap kinerja karyawan.

$\mathrm{H}_{8 \text { : }}$ Budaya organisasi berpengaruh secara positif dan signifikan terhadap kinerja karyawan.

$\mathrm{H}_{9}$ : Komitmen organisasi berpengaruh secara positif dan signifikan terhadap kinerja karyawan.

\section{METODE PENELITIAN}

Penelitian ini merupakan jenis penelitian survey, yaitu penelitian yang dilakukan dengan mengambil sampel secara langsung dari populasi, sehingga ditemukan hubunganhubungan antar variabel (Sugiyono, 2004). Terdapat lima variabel dalam penelitian ini, yaitu kepemimpinan spiritual, 
budaya organisasi, komitmen organisasi, kepuasan kerja dan kinerja karyawan.

Populasi dalam penelitian ini adalah seluruh karyawan BMT se-Kabupaten Pati. Berkaitan dengan jumlah populasi yang relatif banyak, maka dalam penelitian ini digunakan sampel dari populasi. Dalam penelitian ini, ada 3 BMT di Pati yang dijadikan sebagai sampel, yaitu BMT Ya Ummi Fatimah, BMT Al-Fath, dan BMT Fastabiq. Alasan pemilihan ketiga BMT ini dikarenakan ketiga BMT ini dipandang paling besar dan banyak nasabahnya dibandingkan BMT lainnya.

Sementara itu, sampel dalam penelitian ini sebanyak 130 responden. Hal ini sudah memenuhi syarat bahwa untuk penelitian dalam pemodelan analisis jalur (path analysis) adalah antara $10-25$ kali jumlah variabel independen (Ferdinand, 2006). Sedangkan teknik analisis datanya adalah path analysis dengan menggunakan software statistik AMOS 16.0.

\section{HASIL DAN PEMBAHASAN}

\section{Karakteristik Responden}

Responden penelitian ini adalah 130 responden. Karakteristik responden meliputi: jenis kelamin, umur, tingkat pendidikan, masa kerja dan jabatan karyawan dijelaskan dalam tabel sebagai berikut:

Tabel 1. Karakteristik responden

\begin{tabular}{|l|c|c|}
\hline \multicolumn{1}{|c|}{ Karakteristik } & Jumlah & Prosentase \\
\hline Jenis Kelamin & & \\
- Laki-laki & 78 & 60 \\
- Perempuan & 52 & 40 \\
Total & 130 & 100 \\
\hline Umur & & \\
- 20 - 24 Tahun & 40 & 31 \\
- 25 - 29 Tahun & 32 & 32 \\
- 30 - 34 Tahun & 8 & 25 \\
- 35 - 39 Tahun & 8 & 6 \\
- > 40 Tahun & 130 & 6 \\
Total & & 100 \\
\hline
\end{tabular}




\begin{tabular}{|l|c|c|}
\hline Pendidikan & & \\
- SMA & 82 & 63 \\
- Diploma & 18 & 14 \\
Total & 30 & 23 \\
Masa Kerja & 130 & 100 \\
- $1-2$ Tahun & & \\
- 3-4 Tahun & 13 & 10 \\
- 5-6 Tahun & 42 & 32 \\
- > 7 Tahun & 26 & 20 \\
Total & 49 & 38 \\
\hline Jabatan Karyawan & 130 & 100 \\
- Marketing & & \\
- Teller & 18 & 48 \\
- Adm pembiayaan & 26 & 14 \\
- Account Officer (AO) & 8 & 20 \\
- Auditor Internal & 8 & 6 \\
- Risk Finance & 8 & 6 \\
Total & 130 & 100 \\
\hline
\end{tabular}

Sumber: Data primer diolah, 2016.

\section{Uji Estimasi Model dan Pengujian Hipotesis}

Setelah dilakukan uji asumsi model path analysis, yaitu uji normalitas data, uji outlier, dan uji multicollinearity dan singularity menunjukkan bahwa seluruh persyaratan tersebut dapat dipenuhi sehingga dapat dilanjutkan untuk dianalisis dengan model path analysis (analisis jalur) sebagai berikut: 
Iqtishadia, Vol. 9, No. 2, 2016

Gambar 2. Model Path Analysis

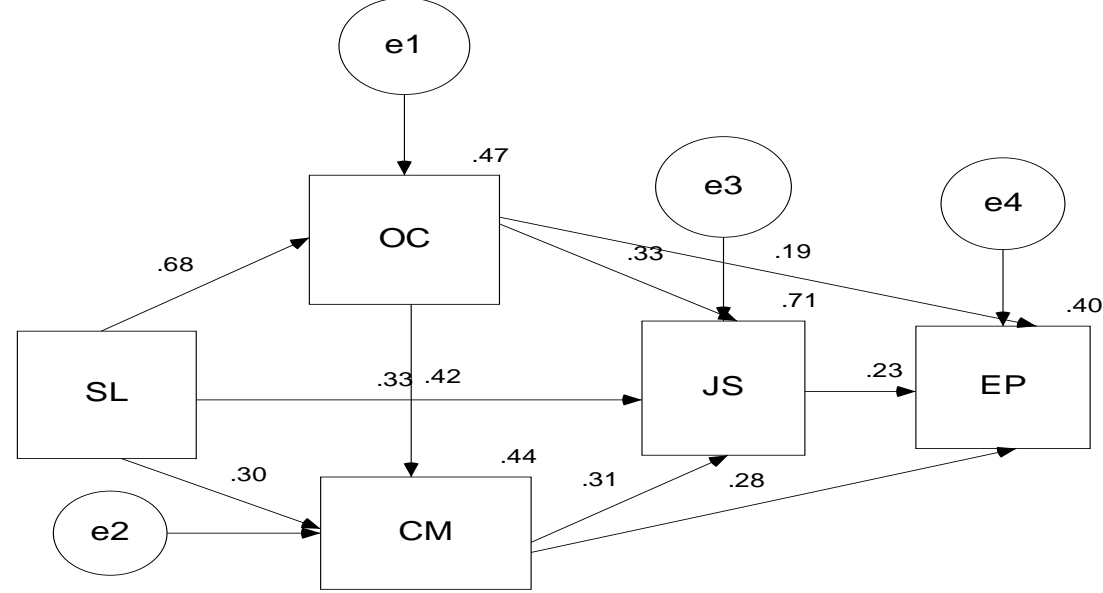

Sumber: Data primer diolah, 2016.

Hasil uji path analysis dapat dilihat dalam tabel sebagai berikut:

Tabel 2. Hasil Uji Path Analysis

\begin{tabular}{|c|c|c|c|c|c|}
\hline $\begin{array}{l}\text { Independet } \\
\text { Variable }\end{array}$ & $\begin{array}{r}\text { Dependent } \\
\text { Variable }\end{array}$ & $\begin{array}{c}\text { Standar } \\
\text { dized Path } \\
\text { Coefficients }\end{array}$ & $C R$ & Prob. & $\begin{array}{c}\text { Squared } \\
\text { Multiple } \\
\text { Correlation } \\
\mathbf{s}\left(\mathbf{R}^{2}\right)\end{array}$ \\
\hline SL & $\mathrm{OC}$ & 0.685 & 10.678 & 0.000 & 0.469 \\
\hline SL & \multirow[t]{2}{*}{$\mathrm{CM}$} & 0.298 & 3.291 & 0.001 & \multirow[t]{2}{*}{0.438} \\
\hline $\mathrm{OC}$ & & 0.420 & 4.639 & 0.000 & \\
\hline $\mathrm{OC}$ & \multirow{3}{*}{ JS } & 0.335 & 4.747 & 0.000 & \multirow{3}{*}{0.709} \\
\hline $\mathrm{CM}$ & & 0.306 & 4.828 & 0.000 & \\
\hline SL & & 0.328 & 4.825 & 0.000 & \\
\hline JS & \multirow{3}{*}{ EP } & 0.229 & 1.971 & 0.049 & \multirow{3}{*}{0.399} \\
\hline OC & & 0.194 & 1.844 & 0.065 & \\
\hline $\mathrm{CM}$ & & 0.284 & 2.878 & 0.004 & \\
\hline
\end{tabular}

Sumber: Data primer diolah, 2016.

Berdasarkan hasil output standardized path coefficients di atas menunjukkan bahwa hasil pengujian terhadap hipotesis penelitian ini adalah: 
1. Pengaruh Kepemimpinan Spiritual terhadap Budaya Organisasi

Hasil perhitungan diperoleh koefisien jalur standardized sebesar 0.685 dengan nilai signifikan pada critical ratio (CR) sebesar 10.678 dengan taraf signifikan 0.000. Oleh karena nilai signifikansi < dari 0,05 maka hipotesis alternatif diterima dan dapat disimpulkan bahwa kepemimpinan spiritual (spiritual leadership) berpengaruh secara positif signifikan terhadap budaya organisasi. Dengan demikian, hipotesis pertama terbukti secara statistik.

2. Pengaruh Kepemimpinan Spiritual terhadap Komitmen Organisasi

Hasil perhitungan diperoleh koefisien jalur standardized sebesar 0.298 dengan nilai signifikan pada critical ratio (CR) sebesar 3.291 dengan taraf signifikan 0.001. Oleh karena nilai signifikansi < dari 0,05 maka hipotesis alternatif diterima dan dapat disimpulkan bahwa kepemimpinan spiritual (spiritual leadership) berpengaruh secara positif signifikan terhadap komitmen organisasi. Dengan demikian, hipotesis kedua terbukti secara statistik.

3. Pengaruh Budaya Organisasi terhadap Komitmen Organisasi

Hasil perhitungan diperoleh koefisien jalur standardized sebesar 0.420 dengan nilai signifikan pada critical ratio (CR) sebesar 4.639 dengan taraf signifikan 0.000 . Oleh karena nilai signifikansi < dari 0,05 maka hipotesis alternatif diterima dan dapat disimpulkan bahwa budaya organisasi berpengaruh secara positif signifikan terhadap komitmen organisasi. Dengan demikian, hipotesis ketiga terbukti secara statistik.

4. Pengaruh Budaya Organisasi terhadap Kepuasan Kerja

Hasil perhitungan diperoleh koefisien jalur standardized sebesar 0.335 dengan nilai signifikan pada critical ratio (CR) sebesar 4.747 dengan taraf signifikan 0.000 . Oleh karena nilai signifikansi < dari 0,05 maka hipotesis alternatif diterima dan dapat disimpulkan bahwa budaya organisasi berpengaruh secara positif signifikan terhadap kepuasan kerja. Dengan demikian, hipotesis keempat terbukti secara statistik.

5. Pengaruh Komitmen Organisasi terhadap Kepuasan Kerja

Hasil perhitungan diperoleh koefisien jalur standardized sebesar 0.306 dengan nilai signifikan pada critical ratio (CR) sebesar 4.828 dengan taraf signifikan 0.000 . Oleh karena nilai 
signifikansi < dari 0,05 maka hipotesis alternatif diterima dan dapat disimpulkan bahwa komitmen organisasi berpengaruh secara positif signifikan terhadap kepuasan kerja. Dengan demikian, hipotesis kelima terbukti secara statistik.

6. Pengaruh Kepemimpinan Spiritual terhadap Kepuasan Kerja

Hasil perhitungan diperoleh koefisien jalur standardized sebesar 0.328 dengan nilai signifikan pada critical ratio (CR) sebesar 4.825 dengan taraf signifikan 0.000. Oleh karena nilai signifikansi < dari 0,05 maka hipotesis alternatif diterima dan dapat disimpulkan bahwa kepemimpinan spiritual (spiritual leadership) berpengaruh secara positif signifikan terhadap kepuasan kerja. Dengan demikian, hipotesis keenam terbukti secara statistik.

7. Pengaruh Kepuasan Kerja terhadap Kinerja Karyawan

Hasil perhitungan diperoleh koefisien jalur standardized sebesar 0.229 dengan nilai signifikan pada critical ratio (CR) sebesar 1.971 dengan taraf signifikan 0.049. Oleh karena nilai signifikansi < dari 0,05 maka hipotesis alternatif diterima dan dapat disimpulkan bahwa kepuasan kerja berpengaruh secara positif signifikan terhadap kinerja karyawan. Dengan demikian, hipotesis ketujuh terbukti secara statistik.

8. Pengaruh Budaya Organisasi terhadap Kinerja Karyawan

Hasil perhitungan diperoleh koefisien jalur standardized sebesar 0.194 dengan nilai signifikan pada critical ratio (CR) sebesar 1.844 dengan taraf signifikan 0.065 . Oleh karena nilai signifikansi > dari 0,05 maka hipotesis alternatif ditolak dan dapat disimpulkan bahwa budaya organisasi tidak berpengaruh terhadap kinerja karyawan. Dengan demikian, hipotesis kedelapan tidak terbukti secara statistik.

9. Pengaruh Komitmen Organisasi terhadap Kinerja Karyawan

Hasil perhitungan diperoleh koefisien jalur standardized sebesar 0.284 dengan nilai signifikan pada critical ratio (CR) sebesar 2.878 dengan taraf signifikan 0.004 . Oleh karena nilai signifikansi < dari 0,05 maka hipotesis alternatif diterima dan dapat disimpulkan bahwa komitmen organisasi berpengaruh secara positif signifikan terhadap kinerja karyawan. Dengan demikian, hipotesis kesembilan terbukti secara statistik.

Kesimpulan hipotesis penelitian dapat dilihat dalam tabel sebagai berikut: 
Tabel 3. Kesimpulan Hipotesis

\begin{tabular}{|c|c|}
\hline Hipotesis & Hasil Uji \\
\hline $\begin{aligned} \mathrm{H}_{1}: & \text { Kepemimpinan spiritual berpengaruh } \\
& \text { secara positif dan signifikan terhadap } \\
& \text { budaya organisasi }\end{aligned}$ & $\begin{array}{l}\text { Didukung } \\
\text { oleh data }\end{array}$ \\
\hline $\begin{aligned} \mathrm{H}_{2}: & \text { Kepemimpinan spiritual berpengaruh } \\
& \text { secara positif dan signifikan terhadap } \\
& \text { komitmen organisasi }\end{aligned}$ & $\begin{array}{l}\text { Didukung } \\
\text { oleh data }\end{array}$ \\
\hline $\begin{array}{l}\mathrm{H}_{3}: \text { Budaya organisasi berpengaruh secara } \\
\text { positif dan signifikan terhadap } \\
\text { komitmen organisasi }\end{array}$ & $\begin{array}{r}\text { Didukung } \\
\text { oleh data }\end{array}$ \\
\hline $\begin{array}{l}\mathrm{H}_{4} \text { :. Budaya organisasi berpengaruh secara } \\
\text { positif dan signifikan terhadap } \\
\text { kepuasan kerja }\end{array}$ & $\begin{array}{l}\text { Didukung } \\
\text { oleh data }\end{array}$ \\
\hline $\begin{aligned} \mathrm{H}_{5}: \text { Komitmen organisasi berpengaruh } \\
\text { secara positif dan signifikan terhadap } \\
\text { kepuasan kerja }\end{aligned}$ & $\begin{array}{c}\text { Didukung } \\
\text { oleh data }\end{array}$ \\
\hline $\begin{array}{l}\mathrm{H}_{6}: . \text { Kepemimpinan spiritual berpengaruh } \\
\text { secara positif dan signifikan terhadap } \\
\text { kepuasan kerja. }\end{array}$ & $\begin{array}{l}\text { Didukung } \\
\text { oleh data }\end{array}$ \\
\hline $\begin{array}{l}\mathrm{H}_{7}: \text { Kepuasan kerja berpengaruh secara } \\
\text { positif dan signifikan terhadap kinerja } \\
\text { karyawan }\end{array}$ & $\begin{array}{l}\text { Didukung } \\
\text { oleh data }\end{array}$ \\
\hline $\begin{array}{l}\mathrm{H}_{8} \text { : Budaya organisasi berpengaruh secara } \\
\text { positif dan signifikan terhadap kinerja } \\
\text { karyawan }\end{array}$ & $\begin{array}{c}\text { Tidak } \\
\text { Didukung } \\
\text { oleh data }\end{array}$ \\
\hline $\begin{array}{l}\mathrm{H}_{9}: \text {. Komitmen organisasi berpengaruh } \\
\text { secara positif dan signifikan terhadap } \\
\text { kinerja karyawan }\end{array}$ & $\begin{array}{l}\text { Didukung } \\
\text { oleh data }\end{array}$ \\
\hline
\end{tabular}

\section{Analisis Direct Effect, Indirect Effect dan Total Effect}

Berdasarkan hasil analisis jalur (path analysis) dapat ditemukan besarnya pengaruh langsung (direct effect), tidak langsung (indirect effect) maupun pengaruh totalnya (total effect) antara variabel eksogenus dan endogenus. Adapun hasil uji direct effect, indirect effect maupun total effect model path analysis dapat dilihat dalam tabel sebagai berikut: 
Iqtishadia, Vol. 9, No. 2, 2016

Tabel 4. Standardized Direct, Indirect dan Total Effects

\begin{tabular}{|c|c|c|c|c|}
\hline $\begin{array}{l}\text { Independet } \\
\text { Variable }\end{array}$ & $\begin{array}{r}\text { Dependent } \\
\text { Variable }\end{array}$ & $\begin{array}{l}\text { Direct } \\
\text { Effects }\end{array}$ & $\begin{array}{c}\text { Indirect } \\
\text { Effects }\end{array}$ & Total Effects \\
\hline SL & $\mathrm{OC}$ & 0.685 & - & 0.685 \\
\hline SL & \multirow[t]{2}{*}{$\mathrm{CM}$} & 0.298 & 0.288 & 0.586 \\
\hline $\mathrm{OC}$ & & 0.420 & - & 0.420 \\
\hline $\mathrm{OC}$ & \multirow{3}{*}{ JS } & 0.335 & 0.129 & 0.463 \\
\hline $\mathrm{CM}$ & & 0.306 & - & 0.306 \\
\hline SL & & 0.328 & 0.409 & 0.736 \\
\hline SL & \multirow{4}{*}{ EP } & - & 0.468 & 0.468 \\
\hline $\mathrm{OC}$ & & 0.194 & 0.226 & 0.420 \\
\hline $\mathrm{CM}$ & & 0.284 & 0.070 & 0.354 \\
\hline JS & & 0.229 & - & 0.229 \\
\hline
\end{tabular}

Sumber: Data primer diolah, 2016.

Berdasarkan hasil penelitian dengan menggunakan path analysis menunjukkan bahwa kepemimpinan spiritual merupakan variabel yang dominan dan memiliki pengaruh terbesar terhadap kepuasan kerja dan kinerja karyawan. Namun, dampak kepemimpinan spiritual terhadap kinerja karyawan tidak terjadi secara langsung, melainkan melalui suatu proses pembentukan nilai-nilai, norma, sikap dan keyakinan karyawan terhadap organisasi sehingga membentuk komitmen, sikap dan perilaku kerja yang produktif.

Kepemimpinan spiritual memiliki peran efektif untuk mendorong, memotivasi dan menggerakkan para karyawan agar berperilaku searah dengan pencapaian visi, misi dan tujuan organisasi. Kepemimpinan spiritual juga mendorong timbulnya ikatan emosional yang kuat dalam diri para karyawan untuk menerima tujuan dan nilai-nilai organisasi, berusaha sebaik mungkin untuk kepentingan organisasi serta memiliki loyalitas yang tinggi terhadap organisasi. Selain itu, kepemimpinan spiritual juga mampu membentuk sikap kerja yang positif terhadap pekerjaannya. Kondisi tersebut mendorong lahirnya 
perasaan nyaman dan menyenangkan (kepuasan kerja) sehingga berdampak pada perilaku kerja yang produktif.

Temuan hasil penelitian ini juga menunjukkan bahwa budaya organisasi tidak memiliki pengaruh yang cukup besar dalam menentukan kinerja karyawan. Oleh karena itu, pimpinan BMT perlu melakukan upaya untuk memperkuat dan meningkatkan budaya organisasi melalui sosialisasi lebih mendalam mengenai visi, misi, nilai-nilai dan norma yang berlaku, melibatkan karyawan dalam setiap kegiatan sehingga terbangun kerja sama yang baik dan rasa saling mmeghargai antar para karyawan maupun karyawan dengan pimpinan serta memberikan kesempatan kepada para karyawan untuk berinteraksi agar terbangun rasa saling percaya dan keterbukaan antar sesama karyawan maupun karyawan dan pimpinan.

Hasil penelitian ini mendukung temuan Musta'in dan Manan (2014) yang menunjukkan bahwa kepemimpinan spiritual berpengaruh secara signifikan terhadap kepuasan kerja dan meningkatkan kinerja karyawan. Hasil penelitian ini juga memberikan dukungan terhadap studi Shofwa (2013) yang juga membuktikan bahwa kepemimpinan spiritual berpengaruh secara signifikan terhadap kinerja karyawan.

Hasil penelitian ini mendukung hasil studi Taurisa dan Ratnawati (2012) serta studi Nurjanah (2008) yang membuktikan bahwa budaya organisasi berpengaruh positif dan signifikan terhadap komitmen organisasi. Hasil penelitian ini juga mendukung studi Widagdo et al. (2013) yang membuktikan bahwa budaya organisasi berpengaruh positif dan signifikan terhadap kepuasan kerja. Namun demikian, hasil penelitian ini tidak konsisten dengan studi Logahan dan Aesaria (2014) yang menunjukkan bahwa budaya organisasi berpengaruh positif dan signifikan terhadap kinerja karyawan.

Hasil penelitian ini mendukung temuan Noor (2012) yang menunjukkan bahwa komitmen organisasi berpengaruh secara signifikan terhadap kepuasan kerja karyawan. Hasil penelitian ini juga mendukung studi Taurisa dan Ratnawati (2012) yang menyatakan bahwa komitmen organisasi berpengaruh efektif terhadap kinerja karyawan. Berdasarkan studi ini, dapat disimpulkan bahwa komitmen organisasi merupakan anteseden kepuasan kerja dan selanjutnya kepuasan kerja mempengaruhi kinerja karyawan. 


\section{PENUTUP}

Berdasarkan pengujian terhadap hipotesis penelitian dapat ditarik kesimpulan sebagai berikut: (1) kepemimpinan spiritual berpengaruh secara positif signifikan terhadap budaya organisasi; (2) kepemimpinan spiritual berpengaruh secara positif signifikan terhadap komitmen organisasi; (3) budaya organisasi berpengaruh secara positif signifikan terhadap komitmen organisasi; (4) budaya organisasi berpengaruh secara positif signifikan terhadap kepuasan kerja; (5) komitmen organisasi berpengaruh secara positif signifikan terhadap kepuasan kerja; (6) kepemimpinan spiritual berpengaruh secara positif dan signifikan terhadap kepuasan kerja; (7) kepuasan kerja berpengaruh secara positif dan signifikan terhadap kinerja karyawan; (8) budaya organisasi tidak berpengaruh terhadap kinerja karyawan; dan (9) komitmen organisasi berpengaruh secara positif signifikan terhadap kinerja karyawan.

Dengan demikian, dalam menjalankan bisnis syari'ah, BMT dan LKMS perlu menerapkan nilai-nilai spiritual dalam memimpin organisasi/perusahaan dalam rangka membentuk dan membangun budaya organisasi dan komitmen organisasi sehingga menghasilkan kepuasan kerja dan kinerja karyawan yang produktif. 


\section{DAFTAR PUSTAKA}

Ferdinand, Augusty. (2006). Structural Equation Modelling dalam Penelitian Manajemen, UNDIP, Semarang.

Fry, Louis W; Vitucci, Steve; Cedillo, Marie. (2005). Spiritual Leadership and Army Transformation: Theory, Measurement and Establishing a Baseline. Leadership Quarterly, 16(5), 835-863.

Ganesan, Shankar and Weitz, Barton A. (1996). The Impact of Staffing Policies on Retail Buyer Job Attitudes and Behaviors. Journal of Retailling, 72(1), 31-56.

Ghozali, Imam. (2002). Pengaruh Religiositas Terhadap Komitmen Organisasi, Keterlibatan Kerja, Kepuasan Kerja dan Produktivitas. Jurnal Bisnis Strategi, 9.

Hakim, Abdul. (2012). The Implementation of Islam leadership and Islamic Organizational Culture and Its Influence on Islamic Working Motivation and Islamic Performance PT Bank Muamalat Indonesia Tbk Employee in the Central Java. Asia Pacific Management Review, 17(1), 77-90.

Hatta, Iha Haryani dan Rachbini, Widiarto. (2015). Budaya Organisasi, Insentif, Kepuasan Kerja dan Kinerja Karyawan pada PT. Avrist Assurance. Jurnal Manajemen, XIX(1), 74-84.

Logahan, Jerry Marcellinus dan Aesaria, Sherley Marcheline. 2014. Budaya Organisasi dan Keterlibatan Kerja terhadap Komitmen Organisasi Berdampak pada Kinerja Karyawan pada BTN Ciputat. Binus Business Review, 5(2), 551-563.

Hofstede, Geert; Bond, Michael Harris and Luk, Chung-leung. (1993). Individual Perceptions of Organizational Cultures: A Methodological Treatise on Levels of Analysis. Organisations Studies, 14(4), 483-503.

Mahmudi. (2005). Manajemen Kinerja Sektor Publik, UPP AMP YKPN, Yogyakarta.

Musta'in, M. Nadjib dan Manan, Anwar Sanusi Abdul. (2014). A Study on Employees Performance: Spiritual Leadership and Work Motivation with Mediation Work Satisfaction at the University of Darul Ulum Indonesia. 
European Journal of Business and Management, 6(39), 77-85.

Noor, Zainul Arifin. (2012). Pengaruh Budaya Organisasi, Komitmen Organisasi dan Motivasi Kerja terhadap Kepuasan Kerja dan Kinerja Karyawan. Ekuitas: Jurnal Ekonomi dan Keuangan, 16(4), 473-486.

Nurjanah. (2008). Pengaruh Gaya Kepemimpinan dan Budaya Organisasi terhadap Komitmen Organisasi dalam Meningkatkan Kinerja Karyawan (Studi pada Biro Lingkup Departemen Pertanian. Tesis, Program Studi Magister Manajemen Program Pascasarjana Universitas Diponegoro Semarang.

Rahim, Abdul Rahman. (2014). The Effect of Islamic Leadership on Distributive Justice and Management Budget (Apb) and Employee Welfare in Islamic Universities in South Sulawesi. IOSR Journal of Business and Management (IOSR-JBM), 16(4), 55-63.

Shofwa, Yoiz. (2013). Pengaruh Motivasi Spiritual dan Kepemimpinan Spiritual terhadap Kinerja Religius Dosen dan Karyawan STAIN Purwokerto. Jurnal Pro Bisnis, 6(1), 1-19.

Sopiah. (2008). Perilaku Organisasional, Andi Offset, Yogyakarta.

Sugiyono. (2004). Metode Penelitian Bisnis, Alfabeta, Bandung. Sulistyo, Heru. (2009). Analisis Kepemimpinan Spiritual dan

Komunikasi Organisasional terhadap Kinerja Karyawan. EKOBIS, 10(2), 311-321.

Sunarno dan Liana, Lie. (2015). Pengaruh Komitmen Organisasional dan Budaya Organisasi terhadap Kinerja Guru Dimediasi Kepuasan Kerja (Studi Kasus pada Guru SMA Kesatrian dalam Yayasan Pendidikan Kesatrian). Prosiding Seminar Nasional Multi Disiplin dan Call for Paper Unisbank, 1-16.

Sureskiarti, Enok. (2015). Pengaruh Spiritual Leadership terhadap Kinerja Perawat dalam Melaksanakan Asuhan Keperawatan di RSUD Dr. H. Soewondo Kendal. Tesis, Program Studi Magister Keperawatan Fakultas Kedokteran Universitas Diponegoro, Semarang.

Taurisa, Chaterina Melina dan Ratnawati, Intan. (2012). Analisis Pengaruh Budaya Organisasi dan Kepuasan Kerja 
terhadap Komitmen Organisasional dalam Meningkatkan Kinerja Karyawan (Studi pada PT. Sido Muncul Kaligawe Semarang). Jurnal Bisnis dan Ekonomi (JBE), 19(1), 170-187.

Tobroni. (2015). Spiritual Leadership: A Solutions of the Leadership Crisis in Islamic Education in Indonesia. British Journal of Education, 3(11), 40-53.

------ (2005). Perilaku Kepemimpinan Spiritual dalam Pengembangan Organisasi Pendidikan dan Pembelajaran. Disertasi, UIN Sunan Kalijaga, Yogyakarta.

Tsui, Anne S., et al. (1997). Alternative to the EmployeeOrganization Relationship: Does Investment in Employees Pay off?. The Academy of Management Journal, 40(5), 1089-1121.

Umam, Khaerul. (2012). Perilaku Organisasi, Pustaka Setia, Bandung.

Vitell, Scott J and Davis, D. L. (1990). The Relationship Between Ethics and Job Satisfaction: An Empirical Investigation. Journal of Business Ethics, 9(6), 489-494.

Wibowo. (2015). Perilaku dalam Organisasi, RajaGrafindo Persada, Jakarta.

Widagdo, Hasbi, et al. (2013). Pengaruh Budaya Organisasi dan Komitmen Organisasi terhadap Kepuasan Kerja Karyawan pada PT. Nutrifood Indonesia di Jakarta. Jurnal Riset Manajemen Sains Indonesia (JRMSI), 4(1), 136-150. 